\title{
TITO'S CONCORDAT - THE 1966 PROTOCOL ON THE NEGOTIATIONS BETWEEN YUGOSLAVIA AND THE HOLY SEE FROM A LEGAL PERSPECTIVE
}

\begin{abstract}
The paper discusses the 1966 Protocol on the Negotiations Between Yugoslavia and the Holy See that has already been subject to several historical analyses focusing primarily on negotiations leading to it rather than the document itself. The initial hypothesis is that the legal profile of the 1966 Yugoslav Protocol may indicate its hidden political weight and a deeper historical meaning. In order to discern it, the paper examines the Protocol as an instrument of international law, aiming at explaining the way its form and substance have reflected difficulties and affected changes in relations between a Communist state and the Roman Catholic Church in Tito's Yugoslavia. Therefore, the paper compares the 1966 Yugoslav Protocol with its Eastern-European equivalents and discusses its impact on further evolution of the Yugoslav constitutional and legal framework.
\end{abstract}

Key words: The Holy See, 1966 Protocol, Concordat, Modus Vivendi, Yugoslavia, communist secularism.

\section{INTRODUCTION}

In 2018, the People's Republic of China and the Holy See signed an agreement concerning the appointment of Roman Catholic bishops serving in China. The agreement provides that, from 2018 on, Chinese Government has the authority to recommend candidates for vacant bishoprics before they get officially appointed by the Pope. This kind of settlement of the so-called 'investiture contest' - the conflict over ability to nominate and install bishops - also known as the concordat arose in medieval Europe, but it is no longer a privileged subject of arrangements between a sovereign state and the Roman Catholic Church. Ever since the end of the Second Vatican Council in 1965, modern concordat agreements normally

Associate Professor, Union University Law School, Belgrade;

e-mail: marko.bozic@pravnifakultet.rs 
stipulate strong state guarantees concerning freedom of religion, including exclusive competence of the Holy See in matters of nomination (and recall) of ecclesial servants. It has been a common practice all over the world ever since, with the single exception of Communist China. ${ }^{1}$

The case of China is not very uncommon, though. During the late 1960s and the early 1970s, the Holy See negotiated and concluded similar arrangements with some Eastern European Communist countries as well. ${ }^{2}$ This resulted from the Ostpolitik of the Pope Paul VI, an intensive diplomatic activity towards the Soviet Union and its satellite states aiming to improve general conditions of Roman Catholics behind the Iron Curtain. Anachronistic as they were, these arrangements were also highly controversial, inasmuch as they privileged a single religious denomination - the Roman Catholic Church - by settling and protecting its special legal status on the basis of an international treaty. The fact that they were concluded with officially atheist regimes made them a particularly thought-provoking issue.

Surprisingly, only one of them, that signed with the Yugoslav Government in 1966, was officially recorded as a concordat agreement. ${ }^{3}$ Some scholars singled it out as "the greatest" 4 and "undoubted success" 5 of the Vatican Ostpolitik. The Western press of the time publicly acclaimed it as "the precedent" and "the model for other communist countries". ${ }^{6}$ However, the official title of the document signed in 1966 was the Protocol on the Negotiations, which implies that it was no more than a supplementary or amending treaty of secondary importance. ${ }^{7}$ The apparent absence of

1 Naturally, there are other, still valid 'old-fashioned-style' concordat agreements concluded before 1965. The most controversial is the so-called Napoleon's Concordat from 1801 which is still in force in three departments of the French region of Grand Est (i.e. Bas-Rhin and Haut-Rhin in Alsace and Moselle Department) allowing authorities of this resolutely laical state to interfere with appointment of new Roman Catholic bishops.

2 More precisely, the so-called Partial Agreement with Hungary from 1964; Protocol on Negotiations Between Yugoslavia and the Holy See from 1966 and, finally, the Protocol concluded between the Holy See and Poland in 1974.

3 Agar y Valverde, J. T. M. de, 2000, Raccolta di concordati, 1950-1999, Citti del Vaticano, Libreria editrice vaticana. Not only does the author find a place in his register for the 1966 Yugoslav Protocol, but, far more indicatively, does not even mention the 1964 Hungarian Partial Agreement or the 1974 Polish Protocol.

4 Vukićević, B., 2018, Foreign Policy Doctrine of the Holy See in the Cold War Europe: Ostpolitik of the Holy See, The Turkish Yearbook of International Relations, 49, p. 119.

5 Carrère d'Encausse, H., 1984, Paul VI et l'Ostpolitik, in: Paul VI et la modernité dans l'Église, Rome, École Française de Rome, p. 551.

6 According to the official Yugoslav press clipping report. AJ, Fond 144, folder 95, unit of description 263/66.

7 Aust, A., 2007, Modern Treaty Law and Practice, Cambridge, Cambridge University Press, p. 27. 
strong bilateral commitments makes a poor impression of its content too. How did this document then become 'a concordat'? The manifest contradiction between the face value of the Protocol's form and substance, on one hand, and subsequent qualifications of this document, on the other, is the central issue to be discussed in this paper. This is not only the doctrinal question but also an indicator of its political and historical relevance.

The 1966 Yugoslav Protocol has already been the subject of several partial analyses focusing less on the document itself, but rather on negotiations leading to it. Starting from the personal archives and Memoirs of Agostino Casaroli, the main protagonist of the Vatican Ostpolitik, later also a Cardinal Secretary of State, Massimiliano Valente's article Santa Sede, Chiesa cattolica e potere politico nella Jugoslavia di Tito ${ }^{8}$ portrayed the Vatican perspective on the parleying. Reciprocally, the seminal volume of the Serbian historian Radmila Radić entitled Država i verske zajednice 1945-1970 offered an exhaustive review of relevant materials from Belgrade Archives of Yugoslavia complemented with Miroslav Akmadžàs research paper Pregovori Svete Stolice i Jugoslavije i potpisivanje protokola iz 1966. godine ${ }^{10}$ based on Zagreb Archives. Unfortunately, none of these authors analyzed either the specific legal form of the document or its broader constitutional and legislative context. Furthermore, despite its relevance, the 1966 Yugoslav Protocol has not yet been seriously examined in cross-case analyses. Moreover, the collective volume The Vatican Ostpolitik 1958-1978, Responsibility and Witness during John XXIII and Paul $V I$, recently edited by András Fejérdy, does not particularly discuss the Protocol of 1966 in any of its chapters. Jonathan Luxmoore's and Jolanta Babiuch's book The Vatican and the Red Flag: The Struggle for the Soul of Eastern Europe also showed relatively little interest in the Yugoslav developments on the matter. Due to the time sequence of the events, Stela Alexander's study entitled Church and State in Yugoslavia since 1945 published in 1979 was deprived of the necessary historical distance and all legal data available to researchers today.

The starting premise of this paper is that the legal profile of the 1966 Yugoslav Protocol may indicate its specific political weight. Therefore, the following lines are an attempt at resolving two interconnected questions: that of the legal nature of the Protocol and, in the context of the latter, its political purpose. In order to achieve this, the further analysis examines the Protocol as an instrument of international law, explaining its form and substance as reflecting the foregoing difficulties and affecting changes in

8 The Holy See, Catholic Church and the Political Power in Tito's Yugoslavia.

9 The State and Religious Communities 1945-1970.

10 Negotiations Between the Holy See and Yugoslavia and Signing the 1966 Protocol. 
relations between the state and church in Tito's Yugoslavia. Aiming for this goal, the paper emphasizes the international context of the document by pointing to contrasts and parallels with its Eastern-European equivalents. Concurrently, it discusses the effects of the Protocol on further evolution of the Yugoslav constitutional and legal framework.

\section{The Form of the Protocol}

The full official title of the document was Protocol on the Negotiations Led Between the Representatives of the Government of the Socialist Federative Republic of Yugoslavia and the Representatives of the Holy See [Protokol o razgovorima koji su vođeni između predstavnika vlade Socijalističke Federativne Republike Jugoslavije i predstavnika Svete Stolice]. ${ }^{11}$ It was concluded in a solemn form, with diplomatic pomp and in the presence of foreign reporters and local press on 25 June 1966. The Protocol was signed by Milutin Morača, a member of the Yugoslav Federal Government and the President of the Federal Commission for Religious Affairs, and Agostino Casaroli, the Undersecretary of the Sacred Congregation for Extraordinary Ecclesiastical Affairs. The Protocol was drafted in two authentic versions - in Italian and Serbo-Croatian. ${ }^{12}$

Yugoslavia ratified this document with a decree of the Federal Government signed by its President Petar Stambolić on 13 July 1966. Alongside the Protocol, this decree as a ratification instrument included two additional documents. One was a brief text entitled simply Proceedings (i.e. the records of the signing ceremony), signed and dated the same as the Protocol. The other are two diplomatic letters framing the arrangement set in section IV of the Protocol and also bearing the date of 25 June 1966. The letters were exchanged between the Cardinal Amleto Giovanni Cicognani, the Pope's State Secretary, and Marko Nikezić, the Yugoslav Foreign Affairs Secretary.

11 A more appropriate English translation of the document would be Protocol on the talks, not negotiations. According to Agostino Casaroli, it was Pope Paul VI who suggested the substitution of the initially proposed term negotiations for talks (Casaroli, A., 2001, Mučeništvo strpljivosti [Croatian translation of Agostino Casaroli, Il martirio della pazienza], Zagreb, Kršćanska sadašnjost, p. 358). For uniformity sake, this paper kept the incorrect translation since it has already been adopted in scholarly writing.

12 Bilingual drafts with Italian as the second official language are a common practice today, even in agreements with countries with official languages other than Romance. "Since the middle of the $20^{\text {th }}$ century there has prevailed the practice of both versions of the agreement being equally authentic and binding." Nermec, D., 2012, Concordat agreements between the Holy See and The Post-Communist countries (1990-2010), Leuven-Paris-Walpole, Peeters, p. 37. 
In Yugoslavia, the Protocol was published in the Official Gazette of the SFRY - International Treaties and Other Agreements Supplement on 6 November $1966 .{ }^{13}$ Curiously enough, after the Pope's ratification, the Holy See had never published this document in its official gazette Acta Apostolicae Sedis, "but only in technical study Enchiridion dei Concordati". ${ }^{14}$ More than a formal peculiarity, the latter detail seems a key one for substantial understanding of the 1966 Protocol.

\section{The Protocol Substance}

"A concordat agreement designates an international treaty concluded between the Holy See and a particular State in order to regulate mutual relations, the position and the activity of the Catholic Church in the State in question." ${ }^{15}$ As any other, the given definition is no more than an ideal-type one ${ }^{16}$ and cannot thus reflect the complex history behind its definiendum. The nearly thousand years' long concordat practice was considerably changed for the last time in the early 1960s. It was the time when the final document of the Second Vatican Council - the Dignitatis humanae Declaration - ended the previous, a hundred years old doctrine of Two perfect societies which "assumed that the State should [...] give a special protection to the Catholic feelings of the population, and integrate

13 Protokol o razgovorima koji su vođeni između predstavnika vlade Socijalističke Federativne Republike Jugoslavije i predstavnika Svete stolice [Protocol on Negotiations Between the Representatives of the Government of the Socialist Federative Republic of Yugoslavia and the Representatives of the Holy See], Službeni list SFRJ - Medunarodni ugovori i drugi sporazumi [Official Gazette of the SFRY - International Treaties and Other Agreements Supplement], No. 11/66, pp. 984-986.

14 Němec, D., p. 40, footnote 33. As a matter of fact, the Yugoslav 1966 Protocol was the only that was published officially. Until the present day, the 1964 Partial Agreement with Hungary, as well as the 1974 Polish Protocol had appeared only unofficially in Bareberini, G. (a cura di), 2008, La politica del dialogo. Le carte Casaroli sull'Ostpolitik vaticana, Bologna, Il Mulino. The English translation of the 1974 Polish Protocol (http://www.concordatwatch.eu/showtopic.php?org_id=931\&kb_header_id=35481 27 July 2020).

15 Němec, D., 2012, p. 27.

16 The contracting partner to the Holy See is not always an independent state. It can also be an international organization (such as the Organization of African Unity), an internationally recognized political movement (such as the PLO) or a federated entity without full sovereignty (such as Swiss canton or German land). On the other hand, many modern concordats are made with the Sovereign Order of Malta as the Pope's "wholly-owned subsidiary". Finally, these agreements are not always designated as concordats. Various terms are in use, with even the 1983 Corpus Juris Canonici interchangeably employing the terms conventio and concordatum. 
Catholic moral and social teaching in State legislation". ${ }^{17}$ Modern Catholic teaching considers the State rather an entity without any religious creed, but with a duty to respect and protect both individual religious liberty, as well as the corporate freedom of the Church. This doctrinal turnover changed the logic of concordat negotiations and stipulations rapidly. The main topic of concordats before the 1960s were mutual concessions resulting in establishment of a confessional state, where privileges granted to the Church by the state had been recompensed by its influence on the appointments of bishops, the ecclesial servants' civil oath and administrative control over their activities. Contrary to the practice of the time, the present-day concordat agreements generally postulate the self-proclaimed exclusion of state authority in religious matters which in turn provide the church with exclusive competence over nomination and installation of clergymen. ${ }^{18}$

Ironically, such an evolution was least perceptible in the resolutely secular people's democracies behind the Iron Curtain. As totalitarian systems, these regimes, per definition, were hostile towards any other concurrent ideology, especially Roman Catholicism, which was regularly targeted as a reactionary pillar of an ancient regime. Such hostilities were mutual and strong. During the long reign of Pius XII (1939-1958), the Pope's official policy of zero-tolerance, far from isolating the Communist regimes, played into their hand. ${ }^{19}$ "Instead of buttressing the self-confidence of local churches, he left them dangerously exposed raising the stakes in a confrontation they could not hope to win". 20 The new Pope John XXIII and the Second Vatican Council he initiated hinted at a new, proactive stance known as the Vatican Ostpolitik ${ }^{21}$ aiming to ease the strained relations and turn them from confrontation and crisis towards

17 Minnerath, R., 2000, The Experience of the Catholic Church in Structuring Relationship with States in the XX Century, Исйорический Вестиник, 9-10. (www.vob.ru/ public/bishop/istor_vest/2000/5-6_9-10/1_16.htm, 26 July 2020).

18 For more about the modern concordat theory and practice see Petkoff, P., 2007, Legal Perspectives and Religious Perspectives of Religious Rights under International Law in the Vatican Concordats (1963-2004), Law \& Justice - The Christian Law Review, 158.

19 Luxmoore, J., Babiuch J., 1998, The Vatican and the Red Flag: The Struggle for the Soul of Eastern Europe, London-Oxford-New York-New Delhi-Sydney, Bloomsbury Academic, p. 94.

20 Ibid., p. 94.

21 As Boris Vukićević pointed out, the journalists subsequently named it "the Vatican Ostpolitik", after the policy of the Chancellor Willy Brandt. The Vatican Ostpolitik actually started before the West German Ostpolitik could be implemented since Brandt became a Chancellor only in 1969. Vukićević, B., 2018, p. 120. 
détente and coexistence. ${ }^{22}$ During the next three decades, Agostino Casaroli, the leading protagonist of this diplomatic campaign, was challenging the government influence in church affairs throughout the Central and Eastern Europe. With varying success, he was seeking either for a modus vivendi as a practical compromise that bypassed difficulties, or a modus non moriendi offering the Church at least a chance of survival. ${ }^{23}$

In a comparative perspective, his achievements in Tito's Yugoslavia were unquestionable. In order to discern the scope of this success, it is necessary to distinguish the signed and ratified main text of the Protocol from a series of documented, yet unofficial verbal statements which were, as succeeding events would confirm, no less important part of the entire arrangement.

\subsection{THE MAIN TEXT: YUGOSLAVIA AS AN EXCEPTION OR A MODEL?}

The main body of the 1966 Yugoslav Protocol is a relatively short text composed of an introductory paragraph tracing the course of the official talks and four brief sections marked by Roman numerals from I to IV. The first two sections describe the official positions of both negotiating parties and express their readiness (i.e. willingness, not duty) to take into consideration any controversial issue that any of the partners would deem worrying and, thus, necessary to be brought to the attention of the other. The section III expresses mutual readiness of both sides to consult each other concerning all issues of interests in their relations. Finally, section IV reestablishes diplomatic relations between Yugoslavia and the Holy See that have been interrupted for fourteen years.

The opening lines of the section I easily explain the scarcity of the Protocol. The official stance of the Yugoslav Government was that the legal position of religious communities was regulated by the Constitution and national legislation grounded on principles such as freedom of religion, separation of the state and the church, equality before the law, etc. ${ }^{24}$ In other words, as Casaroli's Memoirs keep pointing out, the Yugoslav government did not allow for even a theoretical possibility of a particular international treaty with the Holy See to have the legal status of the Roman Catholic Church in Yugoslavia for its subject-matter. ${ }^{25}$ In a multiethnic community with a complex federative composition and delicate his-

\footnotetext{
22 Ibid., p. 118.

23 Luxmoore, J., Babiuch J., 1998, p. 174.

24 Protocol, Sl. list SFRJ, No. 11/66, p. 984, the section I, point 1.

25 Casaroli, A., 2001, pp. 321, 322, 337, 341 and 342, 347.
} 
torical background such as then Yugoslavia, any separate agreement with a particular religious group could have provoked suspicion and disrupted the already fragile interethnic relations. Thus, throughout the official - (as well as unofficial and preparatory) - talks, the Yugoslav delegates were steadily resisting the idea of a concordat agreement as the final outcome of the negotiations. ${ }^{26}$ Instead and from $1964^{27}$ on, the Yugoslav side started proposing a modus vivendi (i.e. a memorandum of understanding). ${ }^{28} \mathrm{Un}$ derstood as a non-legally binding arrangement free of a particular form, such modus vivendi would have expressed no more than a mutual commitment to the factual situation and willingness to discuss pending issues and seek their practical solutions. ${ }^{29}$

Indeed, the 1966 Yugoslav Protocol seems more like an agreement to disagree than a real treaty, let alone a concordat. This impression is only amplified once it is compared with the Hungarian Partial Agreement signed two years earlier. The latter stipulates a series of serious compromises and mutual concessions. In order to release the Roman Catholic Church of severe administrative control of the Hungarian Government, ${ }^{30}$

26 Radić, R., 2002, Država i verske zajednice, Vol. II, pp. 490, 499 and 511.

27 Ibid., p. 504.

28 Today, the term modus vivendi is more frequently used to designate a treaty which is intended to be only temporary or partial. Yet, it is also used to designate memorandum of understandings (Aust, A., 2007, Modern Treaty Law and Practice, Cambridge, Cambridge University Press, p. 31) as an instrument of international law which, unlike treaties, "rather than intending to create international legal rights and obligations, express participants merely wish to record their mutual understandings as to how they will conduct themselves", Aust, A., 2007, p. 20. The Holy See concluded several agreements entitled modus vivendi during the $20^{\text {th }}$ century (with Czechoslovakia in 1927, Ecuador in 1937 and Tunisia in 1964), Němec, D., 2012, p. 40. The Polish government explicitly treated its 1974 Protocol signed with the Holy See as memorandum of understandings, Strzałka, K., The 1974 Polish-Vatican Agreement: New Sources and a New Interpretation, in: Fejérdy, A. (ed.), 2016, The Vatican "Ostpolitik" 1958-1978. Responsibility and Witness during John XXIII and Paul VI, Rome, Viella, p. 239.

29 This modus vivendi formula was provided by professor Milan Bartoš consulted for the first time in October 1964. Regardless of the fact that Bartoš was not an official legal expert of the Yugoslav Government in this matter, his influence on the final redaction of the document was crucial. Not only does the archives material confirm that the document was designed according to his instructions (Cf. AJ, Fond-144, folder 81, unit of description 571 - Beleška o razgovoru sa drugom Milanom Bartošem od 1. oktobra 1964. u Srpskoj akademiji nauka [Note on the Conversation with the Comrade Milan Bartoš on 1 October 1964 in the Serbian Academy of Sciences]), but it also informs that Agostino Casaroli asked to meet him during one of the Belgrade sessions of negotiations, Radić, R., 2002, p. 510.

30 The main concession was the removal of the so-called "ministerial commissaries", popularly known as the "bishops with moustaches" who "[...] did not only restrict the 
the Holy See accepted the divided competence in appointment of bishops, ${ }^{31}$ the state oath for all its ecclesial servants ${ }^{32}$ and the state supervision over the Hungarian pontifical institute in Rome. ${ }^{33}$ Appointment of bishops was the main and certainly the most difficult topic in negotiations with all communist regimes of the time. It also explains the reason why the local Roman Catholic episcopates were usually reserved towards negotiations initiated by the Holy See. They were generally against the talks from which they were excluded, as they were concerned how these talks could affect their positions and authority. This silent resistance to Rome was the strongest in almighty-cardinal Wyszyński's Poland, where the Church was strong due to its own resources. ${ }^{34}$ Such resistance was, though, perceptible throughout the rest of the Communist Europe, except in Tito's Yugoslavia.

Such exception implicitly accounts for the absence of any statechurch arrangement on bishops' investiture in main text of the $1966 \mathrm{Yu}$ goslav Protocol. There was no agreement because there was no conflict before: despite all tensions culminating in interruption of diplomatic relations after Stepinac was created a Cardinal in 1952, the Roman Catholic

bishops' freedom, but when appointing priests they enforced a veritable counter-selection, in as much as they granted their consent only to the appointment of unworthy persons". Fejérdy, A., The Holy See's Negotiations with Budapest and Prague (1963-1978): Criteria for a Comparative Analysis, in: Fejérdy, A. (ed.), 2016, The Vatican "Ostpolitik" 1958-1978. Responsibility and Witness during John XXIII and Paul VI, Rome, Viella, pp. 198 and 199. Casaroli was less successful in Czechoslovakia, where the "government showed a willingness to remove the commissioners only in those places where they had succeeded in agreeing with the Church on the filling of the diocese head post", Ibid., p. 198.

31 "According to the process outlined in the first annex to the agreement, the Holy See could appoint bishops from among candidates appearing on the list submitted by the Hungarian Bench of Bishops - agreed upon in advance with the government, whereas in the case of other candidates (as an 'extraordinary procedure' of sorts), it had to ascertain through direct negotiations or through the president of the Bench of Bishops that the Hungarian government had no objection to the candidate", Ibid., p. 191.

32 The text of the Hungarian state oath, demanding loyalty to "the Hungarian People's Republic, its people and its Constitution was acceptable for the Holy Seen under condition that the oath would not impact on the priestly conscience, in other words, that it in some way it would contain the customary formula sicut decet Episcopum (vel sacerdotem) [i.e. as befits the bishop (or priest) - author's remark]", Ibid., pp. 196 and 197.

33 See Infra, footnote 74.

34 The 1974 Polish Protocol confirmed these assumptions partially since its point 5 excluded the Polish Episcopate from the church-state dialogue by envisaging "consultations on issues of unique and universally recognized ecclesiastical competence of the Holy See, designed to encourage the process of normalization of relations between the Church and the State", Strzałka, K., 2016, p. 249. 
Church in Yugoslavia had never lost the contact with the Holy See. ${ }^{35}$ Relatively free bishops' communication with the Roman Curia and their frequent ad limina visits to Rome after 1956 had never been seriously questioned. ${ }^{36}$ Neither were the papal exclusive competencies in nomination of local bishops. ${ }^{37}$ As Agostino Casaroli admitted, the position of the Roman Catholic Church in Yugoslavia, certainly not a "regular" one, "was far less negative than in other Communist countries". ${ }^{38}$ Institutionally closely tied to Rome, Yugoslav clergy had never got the unexpected autonomy visà-vis Roman Curia that the local catholic hierarchies in Eastern Europe suddenly gained from their imposed isolation. ${ }^{39}$ Thus, contrary to their Polish or Hungarian colleagues, Yugoslav bishops were resolutely against any agreement with the Government settled independently from the Holy See. ${ }^{40}$ Actually, the last lines of section I of the 1966 Yugoslav Protocol ad-

35 It does not mean, however, that the Government competencies in bishops' appointments were not subject to negotiation. The Yugoslav Government was constantly asking to be previously consulted and informed on the Pope's personal decisions. Although no official agreement had been reached on this, there were still some indications that the Holy See used to consult Yugoslav government informally both before (Valente, M., Santa Sede, Chiesa cattolica e potere politico nella Jugoslavia di Tito, in: Fejérdy, A. (a cura di), 2013, La Chiesa cattolica dell'Europa centro-orientale di fronte al comunismo, Roma, Viella, p. 178) and after the 1966 Protocol had been signed (Radić, R., 2002, p. 532).

36 Radić, R., 2002, p. 426.

37 Between 1945 and 1960, the Roman Pontiff appointed 16 new bishops and 6 bishops coadjutors without formally consulting the Yugoslav authorities. Ibid., pp. 434 and 435.

38 Casaroli, A., 2001, p. 320.

39 As a result of this unwanted autonomy, the local episcopates in Poland and Hungary had been leading negotiations with communist regimes and reached provisory agreements commonly known as the modus vivendi (here meaning "temporary agreement" not "memorandum of understanding"). Generally, these documents bartered government guarantees of certain religious liberties (foremost religious instruction in public schools, the Catholic press, caritative church activities, etc.) for explicit bishops' support to the new Communist political order. In practice, these fragile arrangements could not have brought long-lasting solutions in effect, especially because they did not enjoy the Pope's explicit approbation. On the two Polish agreements of this kind (that of 1950 and 1956) see: Mazgaj, M. S., 2010, Church and State in Communist Poland. A History 1944-149, Jefferson, McFarland, pp. 30-52. On Hungarian modus vivendi of 1950 see: Kereszturi, E., 1960, Church-State Relationship in Hungary Since the Communist Takeover in 1945, Master Thesis, Milwaukee, Marquette University, pp. 132-149.

40 This does not mean that Tito's regime did not seek an arrangement with the Yugoslav Episcopate during the 1950s (Valente, M., 2013, pp. 178 and 183). The firm opposition of Yugoslav bishops to these initiatives was strongly encouraged trough their regular contacts with the Holy See admonished by the State Secretary Domenico Tardini: "Without approval by the Holy See, the Church leaders must not in any way 
ditionally confirm government recognition of the exclusive jurisdiction of the Holy See over the Roman Catholic Church in Yugoslavia and provide further guarantees for maintaining regular bishops' contacts with Rome. ${ }^{41}$

In fact, the 1966 Yugoslav Protocol makes an impression of a joint statement about a relatively satisfying status quo of the church-state affairs. Yet, if it was really so, why did this ascertainment of the existing state necessitate a form of a particular, duly signed and ratified, international agreement?

The part of the answer lies in the last - most certainly not the least - point of this document. Since the standards of international law require a mutual consent for establishment of diplomatic relations, ${ }^{42}$ there is no doubt that, regardless of its fairly inappropriate title, the 1966 Yugoslav Protocol is an international agreement, moreover a concordat strictissimo sensu. Namely, according to the definition mentioned above, "A concordat agreement designates an international treaty concluded between the Holy See and a particular State in order to regulate mutual relations [...]", including, a fortiori, the diplomatic ones. An emblematic illustration of this doctrinal stance was offered in the post-communist 1990 Hungarian concordat, a brief treaty establishing full diplomatic relations between $\mathrm{Bu}$ dapest and the Holy See. ${ }^{43}$ This convincing interpretation, however, was

promise anything or confirm anything. Mr. Tardini wrote to Josip Ujčić, the Belgrade Archbishop: 'Not even orally and this Includes the draft or concept of any agreement. This is not only against the Canon Law, but harmful to the Church and to souls." According to Luxmoore, J., Babiuch. J., 1998, p. 104.

41 The asymmetry was a complete one: unlike in the other Eastern European counterparts, Yugoslavia did not actively coordinate its Vatican policy with USSR. If the Yugoslav Episcopate heavily depended on the Holy See, the Yugoslav Government was free of the Soviet state point of view. During this entire period, the Eastern European people's democracies were coordinating their positions with that of the official Moscow. They did it not only in regular annual international conferences of their Communist parties and state authorities in charge of Church policy (Fejérdy, A., 2016, p. 186), but through ad hoc meetings of secret police officers in charge of "fight against the Vatican" as well. (E.g. for Budapest meeting held at the end of July 1967 see Jakubčin, P., Sources of the Czechoslovak Secret Services on the Ostpolitik, in: Fejérdy, A. (ed.), 2016, The Vatican “Ostpolitik" 1958-1978. Responsibility and Witness during John XXIII and Paul VI, Rome, Viella, pp. 177 and 178). Nevertheless, the Yugoslav Government showed interest in the talks that the Holy See led simultaneously with both Hungary and Czechoslovakia and was ready to exchange information with other Communist regimes (Radić, R., 2002, pp. 495 and 527/8). However, the available archival material indicates a lack of confidential communication after 1963 and even a cautious distrust among the Eastern European partners (Ibid., pp. 497 and 527).

42 The Vienna Convention on Diplomatic relations of 1961, Art 2.

43 The 1990 Agreement between the Holy See and the Republic of Hungary. English translation of this document (https://www.concordatwatch.eu/showtopic.php?org id=848\&kb_header_id=30171, 10 October 2020). 
relativized by the fact that diplomatic relations in the particular Yugoslav case, resumed after 14 years of interruption, were not qualified as "full", but only "unofficial". More precisely, the Yugoslav Government expressed "its readiness to allow the residence to an Apostolic Delegate [the Pope's emissary to the Roman Catholic Church in particular state - author's remark] who will, at the same time, be the envoy to the aforementioned Government". 4 Within the same section IV, the Holy See expressed its reciprocal willingness to receive an envoy representing the Yugoslav Government. Yet, in the diplomatic letter attached to the 1966 Protocol, Cardinal Cicognani, the Pope's State Secretary, underlined that "these envoys will act in a capacity of unofficial representatives". However, the same letter, the content of which was approved in the response letter of the Yugoslav Foreign Secretary Nikezić, specified that these envoys would be appointed, acting and recalled in accordance with the norms of the Vienna Convention on Diplomatic Relations, and, consequently, provided with "all personal and real privileges and immunities applied on diplomatic representatives in accordance with the norms of international law and the above-mentioned Convention". ${ }^{45}$ In other words, although "unofficial", the reestablished relations were undoubtedly diplomatic. The fact that they would be elevated to the ambassadorial level without further formalities only four years later affirms the quality of the Protocol as a de facto international agreement by virtue of its real impact on diplomatic relations between Yugoslavia and the Holy See. ${ }^{46}$

Strengthened by the joint statement in which both sides express mutual readiness to consult each other about all issues of interests for their bilateral relations whenever deemed necessary, ${ }^{47}$ this reestablishment of diplomatic contact was generally considered the biggest breakthrough of Vatican Ostpolitik ever. Actually, with the single Cuban exception, Yugoslavia became the first - and the last - Communist state with a diplomatic mission to the Holy See. In other words, Tito's regime did not only grant papal jurisdiction over the Roman Catholic Church in Yugoslavia with this Protocol. By signing and ratifying it, Yugoslavia recognized the

44 State Secretary cardinal Cicognani's letter to Yugoslav Foreign Secretary Marko Nikezić dated 25 June 1966, Sl. list SFRJ, No. 11/66, p. 985.

45 Ibid.

46 Upon the consent of the Yugoslav Government, one that was not published in the Official Gazette of SFRY, but appeared unofficially only as a brief press information in the pro-government newspaper Politika on 15 August 1970. For more details see: Ilić, P., 1977, Ustanova pronuncija u diplomatskom pravu, Međunarodni problemi, 2, and Dupuy, A., 1981, La diplomatie du Saint Siège après le IIe concile du Vatican: le pontificat de Paul VI, 1963-1978, Paris, Téqui, pp. 24-28 and 295-296.

Protocol, Sl. list SFRJ, No. 11/66, p. 985, the section III. 
international legal personality of the Holy See de jure, a concept the mainstream Soviet legal doctrine continuously denied. Only the 1974 Polish Protocol came any closer to this point by virtue of establishing regular working contacts and teams with diplomatic capacities. ${ }^{48}$

Unthinkable in the USSR and its satellite states, this Yugoslav step forward, however, had its logic and explicitly settled compensation. As a matter of fact, the cornerstone of the 1966 Yugoslav Protocol is embedded in the section II that expresses the official position of the Holy See during the talks i.e. its principle stance that "activities of Catholic priests in exercising their priestly duties must remain within the religious and ecclesial limits, so they could not misuse their religious and ecclesial functions for political purposes". ${ }^{49}$ Furthermore, "the Holy See - in accordance with the Catholic moral - disapproves and condemns every act of political terrorism or similar criminal violence whoever its perpetrator may be". 50 Expressing general attitudes of the Roman Catholic Church, these stipulations were not controversial as such. Two complementary commitments listed below were far more delicate, though. These two provisions clearly expressed the readiness of the Holy See to consider the Yugoslav Government allegations concerning particular Catholic priests' involvement in the above-mentioned criminal activities and subject them to prospective canonical proceedings and measures. ${ }^{51}$ Such stipulations had a crucial meaning for the Yugoslav government, to which the influence of Vatican

48 Actually, the head of the Polish working team had the diplomatic rank of a Minister-Counselor plenipotentiary and was assigned to the Polish Embassy in Rome, Dupuy A., 1984, Paul VI et la diplomatie pontificale, in: Paul VI et la modernité dans l'Église, Rome, École Française de Rome, p. 457.

49 Protocol, Sl. list SFRJ, No. 11/66, p. 984, the section II, point 1.

50 Ibid., point 2.

51 Ibid., pp. 984 and 985, the section II, point 2. This kind of stipulation, known as the Kanzelparagraf (or Pulpit Law), was a common feature in similar provisory agreements concluded between the Roman Catholic Church and Communist regimes. E.g. point two of the first chapter in the 1950 Hungarian modus vivendi stipulates: "The Bench of bishops emphatically condemns all subversive activity, regardless of their source, directed against the political and social order of the Hungarian People's republic. It declares that it shall not permit the religious feelings of the Catholic believers to be misused for political purposes against the State" (Kereszturi, E., 1960, p. 141). The two following 1950 Polish modus vivendi provisions are similar: "VII. In accordance with its principles and in condemnation of all acts against the Polish State, the Church shall particularly oppose the misuse of religious feelings for anti-State purposes. VIII. The Church, which condemns all crimes in accordance with its principles, shall combat the criminal activities of underground bands and shall denounce and punish under Canon Law those clergymen who are guilty of participation in any underground activities against the Polish State". (Mazgaj, M., 2010, p. 37). 
on the anti-Yugoslav emigration and its terrorist activities was the main topic throughout the negotiations. Torn for a long time between this unrelenting Government demand and a discrete, yet steady resistance of the Yugoslav Bishops' Conference, the Holy See finally yielded before the ultimatum of the Government which, at one point, threatened to withdraw from the nearly-finished agreement. ${ }^{52}$

\subsection{THE VERBAL NOTES: A YUGOSLAV OR A CROATIAN CASE?}

The strongest opposition to the 1966 Yugoslav Protocol, namely to its section II, came from the Yugoslav Episcopate dominated by Croatian prelates. At the very finish of negotiations, the majority of bishops lead by Cardinal Franjo Šeper, the Archbishop of Zagreb, ${ }^{53}$ were actively working against the Protocol, convinced that signing it would easily "create an impression of it as a successful attempt of the Federal Government to mislead the Holy See in an anti-Croatian direction". 54 Cardinal Šeper initially tried to postpone the conclusion of the arrangement and get some time for its reassessment. ${ }^{55}$ Once he finally obeyed the will of Pope Paul VI, he asked the supreme church authority not to publish the document, or, at least, to allow Yugoslav bishops to publicly express their personal reserves to it. ${ }^{56}$ The fact that the 1966 Yugoslav Protocol had never been published in the Official Gazette of Holy See, but only in the Enchiridion dei Concordati technical study, might indicate that Cardinal Šeper's concerns were at least partly appreciated.

Not the entire Episcopate shared the Cardinal's reserves. Whereas Croatian bishops boycotted the signing ceremony silently, ${ }^{57}$ avoiding also to comment pro or contra the document, the Protocol earned a general acclaim from Belgrade Archbishop Bukatko and all three bishops

52 As Agostino Casaroli's Memoirs testified, the Yugoslav Government firmly rejected the initiative of the Holy See for the reestablishment of bilateral diplomatic relations without concluding a broader agreement (Casaroli, A., 2001, pp. 350 and 352). The interpolation of these commitments was obviously the bottom line of the Yugoslav agenda or, as Casaroli himself effectively pointed out, something that government "absolutely desired as a part of agreement" Casaroli, A., 2001, p. 348.

53 About the official stance of the Yugoslav Episcopate see: Radić, R., 2002, pp. 521 and 522.

54 Casaroli, A., 2001, pp. 360 and 361.

55 Ibid., p. 350.

56 More precisely, to express that "the document had been formulated neither in accordance to their propositions nor in agreement with episcopate", which eventually got a papal permission. Ibid., p. 361.

57 The archival material implicitly suggests Cardinal Šeper's intention not to attend the event. AJ, Fond 144, folder 95, units of description 207/66 and 266/66. 
from Slovenia. ${ }^{58}$ This divided reaction was somewhat expected. Till the end of the 1960s, Yugoslav Communist regime relaxed its relations with Catholics in Slovenia and Vojvodina, ${ }^{59}$ but its struggles with the Roman Catholic Church in Croatia and Bosnia became ever more antagonistic. ${ }^{60}$ Such a distinction between the regime policy vis-à-vis the Roman Catholic Church in Slovenia, which rather "[...] concentrated on the defense of human and ecclesiastical rights", 61 and its policy towards the Roman Catholic Church in Croatia and Bosnia, which has been closely identified with Croatian nationalism, ${ }^{62}$ indicates why and how the 1966 Protocol related to the always burning Yugoslav, or, even more precisely, Croatian question. ${ }^{63}$

58 Radić, R., 2002, p. 535.

59 The situation was the most favorable in Slovenia, where local bishops maintained regular contacts with the Communist authorities and where $80 \%$ of the clergy voted in elections. Radić, R., 2002, p. 421. In Vojvodina, where the overwhelming majority of Roman Catholics were ethnic Hungarians guided by Croat Zvekanović in Bačka, Ukrainian and Greco-Catholic Bukatko in Banat and German Bäuerlein in Syrmia, the situation was mixed, but certainly less tense than in Croatia and Bosnia.

60 Interior regulations that carried out the 1953 federal Statute on Legal Status of Religious Communities enacted by the Bosnian and, especially, Croatian autonomous government in 1961 were conspicuously more severe than the interior regulations enacted in four other Yugoslav federated entities. For more on this see: Božić, M., 2019, Neither Secular State nor Laical Republic? Legal Position of Religious Communities in Communist Yugoslavia - Legal Framework Analysis, Pravni zapisi, 1.

61 Ramet, P. (ed.), 1984, Religion and Nationalism in Soviet and East European Politics, Los Angeles, Duke press policy studies, p. 169.

62 According to Pedro Ramet, such different position of the Roman Catholic Church towards Slovenian nationalism might be explained by the fact that Slovenian nationalism was fainter (Ramet, P. (ed.), p. 168) or by the fact that Slovenia, unlike Croatia, had an ethnically homogenous population (Ramet, P., 1987, Cross and Commissar: The Politics of Religion in Eastern Europe and the USSR, Bloomington, Indiana University Press, p. 98).

63 There are certain parallels with "the heterogeneity of the Czechoslovak Republic". The anti-Catholic interpretation of national history and a high percentage of atheists in the Czech regions were clearly different from the situation in Slovakia, were popular Catholicism was "strongly rooted among the masses, but paralyzed after 1945-48 by heavy persecutions and permanent accusations branding any of its public expressions as 'separatism', 'bourgeois nationalism' or other crimes against the State", Hrabovec, E., The Vatican Ostpolitik and Czechoslovakia. National Aspects of the Political-Ecclesiastical Negotiations, in: Fejérdy, A. (ed.), 2016. The Vatican "Ostpolitik" 1958-1978. Responsibility and Witness during John XXIII and Paul VI, Rome, Viella, pp. 208 and 209. This parallel is backed by the Church official Kokša's replica to the critics of the Yugoslav officials referring to the memorial service for Stepinac held in Rome in 1966 and led by a Czechoslovakian Cardinal Josef Beran. Kokša claimed, inter-alia, that Beran was not an ethnic Slovak, which was clearly an allusion on Croatian separatism, Radić, R., 2002, p. 526. 
During the whole post-war period, the Yugoslav Intelligence Service (UDBA) was struggling against the Ustashe terrorists actively and morally supported by a certain number of Catholic priests of Croatian origin living and working in emigration. Thus, from the very first unofficial meeting in May 1963, Yugoslav negotiators made it clear to their Vatican counterparts that "the emigration issue" would be high on their agenda. In fact, in the early phase of the negotiations, when each side was probing the readiness and expectations of the other, Yugoslav representatives were foremost testing the willingness of Vatican to restrain anti-Yugoslav activities of the Catholic emigration. The main trial in this respect was President Tito's tour in South America scheduled for the late September and early October 1963. The Yugoslav Government expected visits to these states, otherwise home to many anti-Yugoslav emigrants from Croatia, not to be followed by anti-communist rallies. Only once the Holy See had met these expectations ${ }^{64}$ did the Yugoslav Government accept to start the official talks aiming at the conclusion of a modus vivendi and revival of diplomatic relations. ${ }^{65}$ On the other hand, the Yugoslav Government expressed its supportive attitude regarding the dialogue by introducing some new guaranties for religious liberty the Holy See asked for. In early 1965, the Federal Assembly amended the 1953 Statute on Legal Status of Religious Communities by introducing two new federal felonies aimed at sanctioning violations of religious liberties. ${ }^{66}$ This was more than just a reciprocal Yugoslav concession. It was an effective demonstration of prospective methodology for dealing with open questions: instead of a particular concordat agreement with the Roman Catholic Church, considered harmful to the complex Yugoslav ethnic and religious equilibrium, the Federal Government offered adjustments to the national legal framework. In other words, before the official negotiations had even started, the dialogue partners had already set a model for their further undertaking: a gentlemen's agreement.

64 There were some other signs of détente too: if the Yugoslav Government allowed Stepinac to be buried in Zagreb Cathedral, the Holy See would not rush with his beatification. After all, Casaroli wrote in his Memoirs that later governmental demands concerning Stepinac's beatification did not pose any considerable practical problems, Casaroli, A., 2001, p. 337.

65 According to the archival material, the Yugoslav Government changed its official position in the spring of 1964, Radić, R., 2002, p. 504.

66 The 1953 Federal Statute on Legal Status of Religious Communities did not contain any infractions initially, but granted autonomous republic governments the authority to provide for penalties in this subject matter by their early 1960s interior regulations. None of these regulations prior to 1965 sanctioned violation of religious liberty in any form of its manifestation. 
As it has already been pointed out in the text, the 1966 Yugoslav Protocol was no more than a modus vivendi or a memorandum of understanding. It was a non-legally binding document, yet still an arrangement based on strong, trustworthy promises on both sides. This was an acceptable contracting form insomuch as the partners attested their bona fides in the course of the previous unofficial and preparatory talks. Although brief and simple in style and structure, this modus vivendi was a result of a long and exhausting bargain. However, not all of its achievements have been incorporated in it. For tactical reasons, some of the arrangements have been recorded only as informal verbal notes (i.e. separate statements given in writing and initialed by the heads of negotiating teams). ${ }^{67}$ Defined in the Protocol Proceedings as references to the statements the negotiators had verbally exchanged during the talks, ${ }^{68}$ they have not been considered the official part of the Protocol, published neither in Official Gazette nor in the press, but an attached series of moral obligations. ${ }^{69}$ The most relevant among them was surely the one concerning the way of functioning of the St Jerome Illyric College. The status of this pastoral school associated with the ratlines and close to Ustashe emigration after the WWII was one of the main topics during the talks. ${ }^{70}$ The way the two reciprocal verbal notes on this specific issue have been expressed leads to the conclusion that this arrangement must have been settled and implemented even before 1966. More precisely, the Yugoslav note claims that "the current situation shall not be changed [...] as long as the College would serve its purpose, a.k.a. as long as the students' education in the College would respect the Constitution and the social-political system of SFRY" ${ }^{71}$ As it follows from the symmetrical note of the Holy See, the "current situation" im-

67 The 1966 Yugoslav Protocol was no exception. The Hungarian Partial Agreement signed two years earlier also comprised of two parts: the main document containing the concrete results of the negotiations and the appendices called the Protocol the summarized the disputed questions and the two sides' positions regarding them in sixteen points. Hatos, P., Eastern Policy - Western Roots: The Cultural Context of the Vatican's Ostpolitik, in: Fejérdy, A. (ed.), 2016, The Vatican "Ostpolitik" 1958-1978. Responsibility and Witness during John XXIII and Paul VI, Rome, Viella, p. 19.

68 Protocol Proceedings, Sl. list SFRJ, No. 11/66, p. 985.

69 AJ, Fond 144, folder 95, unit of description 220/66 - Informacija o vođenju pregovora sa Vatikanom o sređivanju odnosa između SFRJ i katoličke crkve [Information on Negotiations with the Vatican about Settling the Relationship Between SFRY and the Catholic Church].

70 In the summer of 1963, as a gesture of détente, the Italian Government finally denied stay to Krunoslav Draganović, the Jasenovac concentration camp military chaplain and one of the main protagonists of the ratlines, who used to be living and working at the College of St. Jerome Illyric until 1959. (Radić, R., 2002, p. 493).

71 Verbal Note of the Yugoslav Government No. 4, recorded on 22 April 1966. AJ, Fond 144, folder 95, unit of description 220/66. 
plied the restrictive College admission policy limited only to students of Yugoslav nationality "as long as the inflow of youth from SFRY bishoprics would be sufficient in number" ${ }^{72}$ This seemed to be a sustainable compromise meaning there would be no place for emigrant elements in the College as long as Yugoslav authorities would be ready to issue passports to student priests-to-be coming from Yugoslavia. ${ }^{73}$ Similarly, another verbal note of the Yugoslav Government offered guarantees concerning the Roman Catholic Church real property basis on Yugoslav national law (i.e. the right to buy, reconstruct or built new estates). ${ }^{74}$ On the other hand, in one of its verbal notes, the Holy See confirmed its readiness to act in order to prevent the Catholic emigration activities that might be unfavorable to further development of relations between the Roman Catholic Church and the Yugoslav state. ${ }^{75}$

Alongside verbal notes expressing these gentlemen's agreements not suitable for publication for political reasons, there were two more referring to pending issues for further discussion (concerning the status of priests' associations autonomous from bishops' authority ${ }^{76}$ and the government competencies in appointment of new bishops ${ }^{77}$ ), as well as other two expressing insurmountable differences in attitudes regarding religious instruction in public schools ${ }^{78}$ and the extent of "religious and ecclesial

72 Verbal Note of the Holy See No. 4, recorded on 4 March 1966. AJ, Fond 144, folder 95, unit of description 220/66.

73 This arrangement on St Jerome Illyric College way of functioning resembles to some situations in Hungary and Czechoslovakia. Partial agreement of 1964 with Hungary also brought the Pontifical Hungarian Institute under the government direction. Following the Hungarian and the Yugoslav example, "the Czechoslovak leadership came forward with the demand that oversight of the Sts. Cyril and Methodius Slovak Ecclesiastical Institute in Rome be handed over to the Czechoslovak Church", Fejérdy, A., 2016, pp. 203 and 204. See also: Hrabovec, E., 2016, p. 229.

74 The Verbal Note of the Yugoslav Government No. 7, recorded on 22 April 1966. AJ, Fond 144, folder 95, unit of description 220/66.

75 The Verbal Note of the Holy See No. 1, recorded on 4 June 1965. AJ, Fond 144, folder 95, unit of description 220/66.

76 The Verbal Note of the Yugoslav Government No. 2, recorded on 7 June 1965 and, respectively, Verbal Note of the Holy See No. 2, recorded on the same date. AJ, Fond 144, folder 95, unit of description 220/66.

77 The verbal Note of the Yugoslav Government No. 3, recorded on 8 June 1965 and, respectively, Verbal Note of the Holy See No. 3, recorded on the same date. AJ, Fond 144, folder 95, unit of description 220/66.

78 The Verbal Note of the Holy See No. 5, recorded on 4 March 1966. In the Verbal Note of the Yugoslav Government No. 1 recorded on 7 June 1965, the head of the Yugoslav delegation offered, however, Government guarantees that there would not be any anticlerical school associations any more. AJ, Fond 144, folder 95, unit of description $220 / 66$. 
limits" of priestly activities as a disclaimer of Kanzelparagraf in the section II of the Protocol. ${ }^{79}$

Taken as a whole (i.e. including all verbal notes), the 1966 Yugoslav Protocol between Tito's regime and the Holy See leaves an impression of an unbalanced political deal. In order to resume (only unofficial) diplomatic relations and get something that it practically already had (a full jurisdiction over the Roman Catholic Church in Yugoslavia), the Holy See agreed to serious concessions. In return for getting no religious instruction in public schools, it promised to continue seeking for a compromise in matters that seriously jeopardized its authority (i.e. the status of autonomous priests' associations and government competencies in bishops' nomination). Moreover, it risked losing the trust of a faithful church in Croatia by agreeing to the Government demands regarding the worrying actions of the Croatian Catholic emigration. The scope of 1966 Yugoslav Protocol became clear enough to explain its accompanying political controversies only after this in-depth analysis, especially as related to why and how Cardinal Šeper's attitude "had to take into account the Croatian patriotism of the Yugoslav catholic majority for whom a dialogue with Belgrade appeared to be a yielding to the centralist Serbian State" ${ }^{80}$

Nevertheless, was it really that bad?

Despite all regrets and criticism coming from the Catholic and nationalist ranks in Croatia, ${ }^{81}$ it does not seem so. Ironically - or highly symbolically? - the 1966 Protocol between Yugoslavia and the Holy See had been signed only five days before the Brioni Plenum took place. The theatric fall of Aleksandar Ranković, the mighty head of UDBA intelligence service and the personification of "the centralist Serbian concept of the Yugoslav State", at this Communist party Plenum was a milestone in devolution of Tito's Yugoslavia. After Rankovićs destitution and all through the late 1960's and the early 1970's, the country was passing

79 The Holy See perceived the teaching of Catholic moral and doctrine to be within these limits. The Yugoslav Government did not acknowledge these limits as a disclaimer. The Verbal Note of the Yugoslav Government No. 6, recorded on 22 April 1966 and, respectively, the Verbal Note of the Holy See No. 6, recorded on the same date. AJ, Fond 144, folder 95, unit of description 220/66.

80 Morozzo Della Rocca, R., Agostino Casaroli and the popes of the Ostpolitic, in: Fejérdy, A. (ed.), 2016, The Vatican "Ostpolitik" 1958-1978. Responsibility and Witness during John XXIII and Paul VI, Rome, Viella, p. 57. See also Morozzo Della Rocca, R., La vita cristiana nella Jugoslavia comunista, in: Vaccaro, L. (ed.), 2008, Storia religiosa di Croazia e Slovenia, Milano, Centro Ambrosiano.

81 For more about the cold reception of the 1966 Yugoslav Protocol in the Croatian public see Spehnjak, K., 2001, Tumačenje „Protokola“ o odnosima Jugoslavije i Vatikana iz 1966 u političkoj javnosti Hrvatske, in: Graovac, I. (ur.), Dijalog povjesničaral historičara/Hans-Georg Fleck, Zagreb, Friedrich Naumann Stiftung. 
through serious constitutional reforms tended to transform it from a federation into confederation. As a result of this process, culminating in 1974 Yugoslav Constitution, the legislative competencies in the matter of legal status of religious communities had been transferred from the federal state to federated entities. Instead of a single federal statute, there were eight parallel legislations now. Similar in form and structure, they were not identical, though. Their comparative analysis leads to a surprising, hence certain and safe conclusion: the northwestern federated entities with a Catholic majority (i.e. Slovenia and Croatia) or a significant Catholic minority (i.e. Vojvodina) loosened their regional legislation by granting churches and religious communities extended rights, removing restrictions or attenuating penalties. The evolution of religious instruction, a major topic during the negotiations with the Holy See ten years earlier, was a striking example. According to the 1953 Federal Statute, religious instruction (catechism) was free, but restricted to religious facilities, allowed only after the regular school teaching had ended and conditioned by a previous consent of both parents and the child itself. While Montenegrin, Bosnian and Macedonian legislation from mid-1970s extended an earlier federal restriction by allowing religious instruction only in the time after regular teaching and the "extra-curricular activities", the Slovenian Statute did not mention any of these schedule limitations. Similarly, the Croatian Statute extended religious instruction to any other space that was legally allowed. On the other hand, while Serbian, Montenegrin, Bosnian and Macedonian legislation still explicitly demanded the consent of both parents, Slovenian, Vojvodinian and Croatian legislation used word play by asking for "saglasnost roditelja", a phrase in Serbo-Croatian which, due to its semantics, may refer to both parents or only to one of them. ${ }^{82}$ As for children's consent, the Croatian and Vojvodinian Statutes asked for it only if the minor in question was 14 to 18. Finally, with the obvious Slovenian exception, all Yugoslav entities chose to sanction the violation of these provisions with medium fines or confinement of up to 30 days. ${ }^{83}$ The same differentiation is comparable regarding many other aspects of religious freedom, such as limiting baptism or wedding celebrations, police restrictions on street processions or money collections, confessional school students' rights, priests' presence in hospitals and similar boarding institutions, etc. ${ }^{84}$ Undoubtedly, the Croatian legislation evolved the fur-

82 This point is particularly significant because of the common knowledge of the time that the Roman Catholic Church in Yugoslavia was continuously striving to relax the legislation requesting the consent of both parents to that of only one of them. Radić, R., 2002, p. 487. Casaroli, A., 2001, p. 339.

83 Božić, M., 2019, pp. 54-56.

84 For more on this see: Ibid., pp. 45, 47, 54 and 58. 
thest. For instance, the highly controversial state administrative control over religious schools (followed by the 1961 restrictive interior regulation of the Croatian autonomous government) had been replaced by the 1978 Croatian Statute and its convincingly most lax rules in this matter in comparisons with the legislation of the seven other Yugoslav federated republics and provinces. ${ }^{85}$ Hardly a coincidence, these digressions may hint at a more ambitious conclusion: more than reestablishment of diplomatic relations and Tito's official visit to Vatican in $1971,{ }^{86}$ such differentiated evolution of Yugoslav legal framework was by far the most intriguing consequence of the 1966 Yugoslav Protocol as the highest point in Vatican Ostpolitik ever. ${ }^{87}$

\section{Conclusion}

In 1801, the French revolutionary state and the Roman Catholic Church signed an agreement ending a more than a decade long anticlerical phase of the French Revolution. This so-called, "Napoleon's concordat" announced the end of the Revolution by renouncing its firm laical legacy.

In 1966, the Yugoslav revolutionary state took the same way.

Actually, the 1966 Protocol on Negotiations Between Yugoslavia and the Holy See was a document of a hybrid nature. According to the inten-

85 Ibid., pp. 53 and 54.

86 Commonly seen as the highest point of the Ostpolitik, Tito's visit to Pope Paul VI in spring of 1971 was not, however, the first official state visit of a Communist leader to the Holy See. Two years before Tito, it was Mika Špiljak, the President of SFRY Federal Government who visited Vatican officially. For more about Tito's official visit to the Holy See see: Tomašević, S., 2011, Tito u Vatikanu, Zagreb, Profil or Bajc, G., 2014, Dietro le quinte della visita di Tito a Roma nel 1971: il contest locale e internazionale letto dalla diplomazia Britannica. Annales: Annals for Istrian and Mediterranean Studies. Series Historia et Sociologia, 4.

87 It is noteworthy that, soon after Tito's official visit to Pope Paul VI in 1971, the College of St. Jerome Illyric [Collegium Hieronymianum Illyricorum] was renamed into Pontifical Croatian College of St. Jerome [Pontificium Collegium Croaticum Sancti Hieronymi], the name it has borne ever since. This is an indicative point since, all the way from its beginnings, the name of the College was an important political issue. Namely, the College was founded in 1901 by Pope Leon XIII under the name College of St. Jerome for the Croatian People [Collegium Hieronymianum pro Croatica Gente], but it was soon renamed under the intervention of the Montenegrin Government, which claimed that the College schooled clerics of Serbian origin as well. The College preserved its nominal Yugoslav character during the inter-war period due to the 1924 Roma treaty signed between Italy and Yugoslavia and the 1928 gentlemen's agreement between Yugoslavia and the Holy See. The archival material, as well as Agostino Casaroli's Memoirs confirm that Croatian/Yugoslav identity of the priestschool remained disputable during the negotiations. Casaroli, A., 2001, pp. 328 and 329; Radić, R., 2002, p. 508. 
tions of the contracting parties inferred from the terms of the document and the circumstances of its conclusion, the 1966 Protocol was less of an international treaty and more of a memorandum of understanding or - to employ the term that contracting parties themselves preferred to use - a modus vivendi as an only morally obliging gentlemen's agreement. Furthermore, for confidentiality reasons, some of the arrangements reached had been registered only as verbal confidential notes attached to the act and not as its official part. The soft form of the settlement was a Yugoslav request. As a multiethnic community with a complex federative composition and delicate historical background, Yugoslavia risked to disrupt fragile interethnic equilibrium by concluding an exceptional international treaty with the Roman Catholic Church. Hence, throughout the talks, the Yugoslav Government steadily resisted the idea of signing a concordat as the final outcome of the negotiations.

Nevertheless, the very form of the 1966 Yugoslav Protocol - a signed and ratified legal instrument - denies the strong attitude of the Government and gives right to Vatican officials to classify it as a concordat agreement. This settlement, namely, served as a legal basis for revival of diplomatic relations between Yugoslavia and the Holy See interrupted fourteen years before. Since the norms of modern international law require a mutual consent for establishment of diplomatic relations, the 1966 Yugoslav Protocol cannot be qualified but as an international agreement (i.e. a concordat). Though 'unofficial', the reestablished relations were undoubtedly diplomatic. The fact that only four years later they would be elevated to the ambassadorial level without further formalities proves positively the international agreement quality of the Protocol.

The hybrid nature of the 1966 Protocol reveals its political purpose in effect. Non-legally binding, the provisions of this 1966 Yugoslav Protocol had a remarkable political weight manifested in a dialectic play of its form and substance. The soft legal form of the Protocol hides its hard-political core: a bitter deal between an atheist regime that agreed to tolerate an unruly church in return for its proactive stand and silent obedience. Perceived in a broader historical perspective, this compromise looks less like an armistice and more like a setup for a long-lasting cohabitation. A detailed analysis of eight parallel Yugoslav regional legislations enacted in the subsequent years validates this conclusion. Unlike Yugoslav southeastern federated entities with a majority Orthodox or Muslim population, the Yugoslav northwestern federated entities with a Catholic majority or an important Catholic minority markedly relaxed their legislations by granting religious communities with extended rights, removing restrictions or attenuating penalties. Even if this contrasted evolution became possible 
only after the devolution of Tito's Yugoslavia by its last 1974 Constitution, it is less likely that it would have taken this direction without the 1966 compromise. This gives rise to a new perception of the 1966 Yugoslav Protocol. Commonly understood as a mere modus vivendi that was supposed to keep a status quo in order to maintain a fragile inter-ethnic balance, this agreement in effect announced a reverse process. As such, the 1966 Yugoslav Protocol was perhaps not a proper concordat de jure, but surely its de facto surrogate of Tito's doing.

\section{BIBLIOGRAPHY}

1. Agar y Valverde, J. T. M., de, 2000, Raccolta di concordati, 1950-1999, Citti del Vaticano, Libreria editrice vaticana.

2. Akmadža, M., 2004, Pregovori Svete Stolice i Jugoslavije i potpisivanje protokola iz 1966. godine [Negotiations between the Vatican and Yugoslavia and the signing of the 1966 Protocol], Časopis za suvremenu povijest, 2.

3. Alexander, S., 1979, Church and State in Yugoslavia since 1945, Cambridge, Cambridge University Press.

4. Aust, A., 2007, Modern Treaty Law and Practice, Cambridge, Cambridge University Press.

5. Bajc, G., 2014, Dietro le quinte della visita di Tito a Roma nel 1971: il contest locale e internazionale letto dalla diplomazia Britannica, Annales: Annals for Istrian and Mediterranean Studies. Series Historia et Sociologia, 4.

6. Bareberini, G. (a cura di), 2008, La politica del dialogo. Le carte Casaroli sull'Ostpolitik vaticana, Bologna, Il Mulino.

7. Božić, M., 2019, Neither secular state nor laical republic? Legal position of religious communities in communist Yugoslavia - legal framework analysis, Pravni zapisi, 1.

8. Carrère d'Encausse, H., 1984, Paul VI et l'Ostpolitik, in: Paul VI et la modernité dans l'Église, Rome, École Française de Rome.

9. Dupuy, A., 1981, La diplomatie du Saint Siège après le IIe concile du Vatican: le pontificat de Paul VI, 1963-1978, Paris, Téqui.

10. Dupuy, A., 1984, Paul VI et la diplomatie pontificale, in: Paul VI et la modernité dans l'Église, Rome, École Française de Rome.

11. Fejérdy, A., The Holy See’s Negotiations with Budapest and Prague (1963-1978): Criteria for a Comparative Analysis, in: Fejérdy, A. (ed.), 2016, The Vatican "Ostpolitik" 1958-1978. Responsibility and Witness during John XXIII and Paul VI, Rome, Viella.

12. Hatos, P., Eastern Policy - Western Roots: The Cultural Context of the Vatican's Ostpolitik, in: Fejérdy, A., 2016, The Vatican "Ostpolitik" 1958-1978. Responsibility and Witness during John XXIII and Paul VI, Rome, Viella.

13. Hrabovec, E., The Vatican Ostpolitik and Czechoslovakia. National Aspects of the Political-Ecclesiastical Negotiations, in: Fejérdy, A., 2016, The Vatican "Ostpolitik" 1958-1978. Responsibility and Witness during John XXIII and Paul VI, Rome, Viella. 
14. Ilić, P., 1977, Ustanova pronuncija u diplomatskom pravu [Institution of pronuncio in diplomatic law], Međunarodni problemi, 2.

15. Jakubčin, P., Sources of the Czechoslovak Secret Services on the Ostpolitik, in: Fejérdy, A. (ed.), 2016, The Vatican “Ostpolitik” 1958-1978. Responsibility and Witness during John XXIII and Paul VI, Rome, Viella.

16. Kereszturi, E., 1960, Church-State Relationship in Hungary Since the Communist Takeover in 1945, Master Thesis, Milwaukee, Marquette University.

17. Luxmoore, J., Babiuch, J., 1998, The Vatican and the Red Flag: The Struggle for the Soul of Eastern Europe, London-Oxford-New York-New Delhi-Sydney, Bloomsbury Academic.

18. Mazgaj, M. S., 2010, Church and State in Communist Poland. A History 1944-149, Jefferson, McFarland.

19. Morozzo Della Rocca, R., La vita cristiana nella Jugoslavia comunista, in: Vaccaro, L. (ed.), 2008, Storia religiosa di Croazia e Slovenia, Milano, Centro Ambrosiano.

20. Morozzo Della Rocca, R., Agostino Casaroli and the Popes of the Ostpolitic, in: Fejérdy, A. (ed.), 2016, The Vatican "Ostpolitik" 1958-1978. Responsibility and Witness during John XXIII and Paul VI, Rome, Viella.

21. Němec, D., 2012, Concordat agreements between the Holy See and The PostCommunist countries (1990-2010), Leuven-Paris-Walpole, Peeters.

22. Petkoff, P., 2007, Legal Perspectives and Religious Perspectives of Religious Rights under International Law in the Vatican Concordats (1963-2004), Law \& Justice The Christian Law Review, 158.

23. Radić, R., 2002, Država i verske zajednice 1945-1970 [State and Religious Communities 1945-1970], Vol. II, Beograd, INIS.

24. Ramet, P. (ed.), 1984, Religion and nationalism in Soviet and East European Politics, Los Angeles, Duke press policy studies.

25. Ramet, P., 1987, Cross and Commissar: The Politics of Religion in Eastern Europe and the USSR, Bloomington, Indiana University Press.

26. Spehnjak, K., 2001, Tumačenje „Protokola“ o odnosima Jugoslavije i Vatikana iz 1966. u političkoj javnosti Hrvatske [Interpretation of Protocol about Relations between Yugoslavia and Vatican in 1966: Echo in Public in Croatia], in: Graovac, I. (ur.), Dijalog povjesničara/historičara/Hans-Georg Fleck, Zagreb, Friedrich Naumann Stiftung.

27. Strzałka, K., The 1974 Polish-Vatican Agreement: New Sources and a New Interpretation, in: Fejérdy, A. (ed.), 2016, The Vatican "Ostpolitik" 1958-1978. Responsibility and Witness during John XXIII and Paul VI, Rome, Viella.

28. Tomašević, S., 2011, Tito u Vatikanu [Tito in Vatican], Zagreb, Profil.

29. Valente, M., Santa Sede, Chiesa cattolica e potere politico nella Jugoslavia di Tito, in: Fejérdy, A. (a cura di), 2013, La Chiesa cattolica dell'Europa centro-orientale di fronte al comunismo, Rome, Viella.

30. Vukićević, B., 2018, Foreign Policy Doctrine of the Holy See in the Cold War Europe: Ostpolitik of the Holy See, The Turkish Yearbook of International Relations, 49. 


\title{
INTERNET SOURCES
}

1. Minnerath, R., 2000, The Experience of the Catholic Church in Structuring Relationship with States in the XX Century, Иситорический Весииник, 9-10. (www. vob.ru/public/bishop/istor_vest/2000/5-6_9-10/1_16.htm, 26 July 2020).

2. http://www.concordatwatch.eu/showsite.php?org_id=843.

\section{Other Sources}

1. The Archives of Yugoslavia, Fond 144 - Savezna Komisija za verska pitanja [Federal Commission for Religious Affairs].

2. Protokol o razgovorima koji su vođeni između predstavnika vlade Socijalističke Federativne Republike Jugoslavije i predstavnika Svete stolice [Protocol on negotiations between the representatives of the government of Socialist Federative Republic of Yugoslavia and the representatives of the Holy See], Sl. list SFRJ - Medunarodni ugovori i drugi sporazumi [Official Gazette of the SFRY - International treaties and other agreements], No. 11/66, pp. 984-986. Abbr. Protocol, Sl. list SFRJ, No. 11/66.

3. Casaroli, A., 2001, Mučeništvo strpljivosti [Croatian translation of Agostino Casaroli, Il martirio della pazienza], Zagreb, Kršćanska sadašnjost.

\section{TITOV KONKORDAT - PRAVNA PRIRODA PROTOKOLA O RAZGOVORIMA IZMEĐU JUGOSLAVIJE I SVETE STOLICE IZ 1966.}

\author{
Marko Božić
}

\section{REZIME}

U pokušaju da popravi položaj katolika iza Gvozdene zavese, Sveta stolica je šezdesetih i sedamdesetih godina prošlog veka sklopila sporazume sa nekoliko istočnoevropskih komunističkih režima od kojih je, međutim, samo onaj zaključen sa Jugoslavijom 1966. smatran konkordatom. Polazeći od namere ugovornih strana utvrđenih na osnovu teksta sporazuma, ali i okolnosti pod kojima je on zaključen, u radu se dolazi do zaključka da je Protokol o razgovorima između predstavnika jugoslovenske vlade $i$ Svete stolice manje bio međunarodni ugovor, a više memorandum o razumevanju, odnosno, rečima samih ugovornih strana, jedan modus vivendi u smislu tek moralno obavezujućeg sporazuma. Ovaj zaključak potkrepljuje i činjenica da su iz političkih razloga neki od dogovora postignutih tokom pregovora bili registrovani samo kao usmene izjave koje su pratile sporazum, a da zvanično nisu bile njegov deo. Meka forma sporazuma bila je uslov jugoslovenske strane. Kao multietnička zajednica sa složenim federativnim uređenjem i osetljivom istorijskom pozadinom, Jugoslavija 
bi potpisivanjem posebnog međunarodnog sporazuma sa Svetom stolicom rizikovala da ugrozi svoju krhku unutrašnju nacionalnu ravnotežu.

Pa ipak, upravo forma Protokola iz 1966. negira ovaj čvrst stav jugoslovenske vlade i daje za pravo vatikanskim zvaničnicima da ga klasifikuju kao konkordat. Naime, ovaj sporazum je poslužio i kao pravni osnov za obnovu diplomatskih odnosa između Titove Jugoslavije i Svete stolice. Kako standardi međunarodnog prava zahtevaju uspostavljanje diplomatskih odnosa na osnovu međusobne saglasnosti strana, Protokol iz 1966. je morao biti sklopljen kao potpisani i ratifikovani međunarodni ugovor, odnosno kao konkordat. Mada „nezvanični“, obnovljeni odnosi su i dalje bili diplomatski. Činjenica da su samo četiri godine kasnije ti odnosi podignuti na najviši nivo bez dodatnih formalnosti, takođe ide u prilog tvrdnji da je Protokol bio međunarodni ugovor.

Hibridna pravna priroda Protokola iz 1966. objašnjava njegovu političku svrhu. Ako odredbe ovog sporazuma najvećim delom i nisu bile pravnoobavezujuće, imale su ozbiljnu političku težinu. Na to upućuje dijalektička igra forme i sadržine ovog sporazuma. Meka pravna forma sporazuma skriva njegovo tvrdo političko jezgro: gorak sporazum jednog ateističkog režima koji prihvata da toleriše jednu neukrotivu crkvu u zamenu za njenu prećutnu saradnju. Sagledan u široj istorijskoj perspektivi, Protokol iz 1966. manje liči na sporazum o primirju, a više na osnov dugoročne kohabitacije. Detaljna analiza osam paralelnih jugoslovenskih zakonodavstava koja će stupiti na snagu u narednom periodu ide u prilog istom zaključku: za razliku od jugoistočnih jugoslovenskih federalnih jedinica sa muslimanskom ili pravoslavnom većinom, jugoslovenske severozapadne federalne jedinice sa katoličkom većinom ili značajnom manjinom su sredinom sedamdesetih vidno relaksirale svoja zakonodavstva obezbeđujući šira prava, ublažavajući ograničenja i umanjujući kazne namenjene verskim zajednicama. A ako je ova divergentna evoluciju postala moguća tek nakon devolucije Titove Jugoslavije po osnovu Ustava iz 1974, nije sigurno da bi pošla istim putem bez kompromisa iz 1966. Otud i nova percepcija Protokola iz 1966: najčešće viđen tek kao modus vivendi zaključen da bi se sačuvao status quo i međuetnička ravnoteža, ovaj sporazum je zapravo najavio obratan proces. Stoga, čak i ako Protokol iz 1966. nije bio konkordat de jure, nesumnjivo da je de facto bio Titov surogat istog.

Ključne reči: Sveta stolica, Protokol iz 1966, Konkordat, modus vivendi, Jugoslavija, komunistička sekularnost.

\section{Article History}

Received: 27 September 2020

Accepted: 25 November 2020 